\title{
HUMAN POTENTIAL DEVELOPMENT IN CHERNIVTSI REGION: THE ROLE OF SOCIAL INFRASTRUCTURE
}

\author{
Victor TELESHMAN \\ Taras Shevchenko National University of Kyiv, Ukraine \\ oscar1424lal@gmail.com
}

\begin{abstract}
An important role in opportunity-building to ensure decent living conditions and to improve the human capacity of any territory is played by development and quality functioning of all elements of a large social complex, but their underdevelopment in contemporary realities could have an impact on decline in key socioeconomic indicators of quality of life and social well-being, and at the same time could be one of the main disincentives of state growth and existence in general. In turn, insufficient study of the influence of social infrastructure on people, their potential on regional level, makes it impossible to build effective integrated development strategies and reflects a low level of awareness of the real issues on the ground. In terms of historical characteristics, geographical location, economic and demographic features of the territory, Chernivtsi region was chosen for the study. The main objectives were to study the dynamics of formation and functioning of certain elements of social infrastructure of the region, their problems and solutions for the region as a whole. The article analyzes the system of indicators characterizing main categories of social infrastructure of the region under study. A number of problems have been identified, the main ones considered to be reduction of the total number of infrastructure and providers of services to the public and significant disparities in social infrastructure development between rural areas and urban settlements. Complex maps have been built, that reflect the state of individual components of social infrastructure and graphs that demonstrate the dynamics of the studied indicators in the region. A number of quick and effective measures to improve the state of social infrastructure in Chernivtsi region are proposed, aimed at overcoming existing problems and providing the harmonious development of people and their potential.
\end{abstract}

Key words: social infrastructure, development, human potential, quality of life, Chernivtsi region, educational complex, medical complex.

DOI: https://doi.org/10.17721/2413-7154/2021.86.67-76

UDC: 911.3

Received: December 01, 2021.

Revised: December 30, 2021.

Accepted: December 31, 2021.

\section{РОЛЬ СОЦІАЛЬНОЇ ІНФРАСТРУКТУРИ У РОЗВИТКУ ЛЮДСЬКОГО ПОТЕНЦІАЛУ НАСЕЛЕННЯ ЧЕРНІВЕЦЬКОӦ ОБЛАСТІ}

\author{
Віктор ТЕЛЕШМАН \\ Київський національний університет імені Тараса Шевченка, Україна \\ oscar1424lal@gmail.com
}

\begin{abstract}
Анотація: Важливу роль у формуванні можливостей для забезпечення гідних умов життя та підвищення рівня людського потенціалу населення будь-якої території $\epsilon$ розвиток та якісне функціонування всіх елементів великого комплексу соціальної інфраструктури, недостатній розвиток якої в сучасних реаліях несе загрозу не лише впливаючи на зниження основних соціально-економічних показників якості життя та благополуччя суспільства, але й виступаючи одним із головних дестимуляторів розвитку та існування інституції держави в цілому. В свою чергу, недостатнє вивчення впливу соціальної інфраструктури на людину, її потенціал на регіональному рівні, унеможливлює формування дієвих комплексних стратегій розвитку та відображає низький рівень обізнаності із реальними проблемами на місцях. 3 точки зору особливостей історичного розвитку, географічного положення та економічних і демографічних особливостей території для дослідження було обрано Чернівецьку область, а основними завданнями було поставлено дослідити динаміку формування та функціонування окремих елементів соціальної інфраструктури регіону, простежити територіальні відмінності у їх розвитку та визначити основні проблеми і шляхи їх вирішення для області в цілому. У статті проаналізовано систему показників, що характеризують основні категорії соціальної інфраструктури досліджуваного регіону. Виявлено низку проблем, головними з яких є скорочення загальної кількості об'єктів інфраструктури та суб'єктів, що надають послуги населенню та значні диспропорції соціально-інфраструктурного розвитку між сільською місцевістю та міськими поселеннями. Побудовано комплексні карти, що відображають стан окремих складових соціальної інфраструктури та графіки, які вказують на динаміку досліджуваних показників у регіоні. Запропоновано ряд швидких та дієвих заходів 3 покращення стану соціальної інфраструктури у Чернівецькій області, що направлені на подолання наявних проблем та забезпечення гармонійного розвитку людини та її потенціалу.
\end{abstract}

Ключові слова: соціальна інфраструктура, розвиток, людський потенціал, якість життя, Чернівецька область, освітній комплекс, медичний комплекс. 
Постановка проблеми. Одним із найголовніших стратегічних напрямків світового суспільства $є$ підвищення рівня та якості життя населення та розвиток людського потенціалу при дотриманні ключових парадигм сталого розвитку. Вирішення даних завдань є особливо важливим i для України, адже покращення основних соціально-економічних показників $\epsilon$ рушійною силою не тільки для задоволення потреб населення, можливості їх реалізації, але й для загальної конкурентоспроможності нашої держави на світовій арені.

Потенціал людини, соціальних спільнот та загалом населення всієї країни слугує яскравим маркером можливостей суспільства. Прояв, активізація, функціонування людського потенціалу, чи, навпаки, його «затухання», стагнація, деформація і деградація залежать від цілої низки зовнішніх, по відношенню до самого потенціалу, соціальноекономічних факторів, насамперед від соціальноекономічної структури, можливостей соціальної вертикальної та горизонтальної мобільності носіїв потенціалу, а зважаючи на те, що зовнішні ресурси (матеріальні, духовні, фінансові тощо) є лише умовою формування, розвитку, реалізації та використання людського потенціалу (Ivanov, 2013) зростає потреба врахування ключових елементів, що здійснюють вплив на нього.

На сьогоднішній день все більш важливого значення набуває політика держави направлена на покращення соціально-економічного становища на макро- та мезорівнях, а важливою ланкою такої політики є підтримка та розвиток соціальної інфраструктури, яка $\epsilon$ основою для відтворення сил та здоров'я людини, покращення як окремих напрямків розвитку суспільства, так і якості його життя в цілому (Yagodka, 2000; Kinash, 2012; Pihul, 2013, 2014). Соціальна інфраструктура, як свідчить досвід розвинених країн, є однією 3 головних складових економіки, яка безпосередньо впливає на сферу життєдіяльності людей та на внутрішньогосподарські функції розвитку, відіграє важливу роль у вирішенні соціальних проблем суспільства, а від рівня іiі розвитку залежить ефективність вирішення не тільки соціальних, економічних, але й політичних та інших проблем держави (Gukalova, 2009; Social infrastructure..., 2018). Відповідно, гостра проблема комплексного та рівномірного розвитку регіонів України та зростання людського потенціалу населення в тому числі матиме вирішення безпосередньо за рахунок покращення якості та функціонування основних структурних елементів соціальної інфраструктури, до якої відносяться організації таких видів економічної діяльності як охорона здоров'я, освіта, культура, спорт, житлово-комунальне господарство, а також установи, які виконують інфраструктурні функції (наприклад, підприємства транспорту, торгівлі, готельно-ресторанного бізнесу тощо) та культурні, історичні, архітектурні пам'ятки, місця дозвілля та відпочинку (Saliy, 2012; Bohun, 2013).

Важливий внесок у дослідження соціальної інфраструктури в цілому та ii впливу на розвиток потенціалу людини, ii рівня життя зробили Б. Данилишин, Е. Лібанова, В. Куценко, О. Алімова, Ц. Будаєва, I. Кінаш, О. Салій, В. Іванов, Н. Плащинський, О. Палій, А. Шаріпов та ін. Дослідженням проблем розвитку соціальної інфраструктури та розробками інституціональних механізмів реструктуризації іiі галузей в Україні займався відділ соціальної інфраструктури інституту демографії та соціальних досліджень ім. М. В. Птухи. Проте, питання розвитку соціальної інфраструктури таїї впливу на людський потенціал на регіональному рівні вивчено недостатньо, що вказує на доцільність даного дослідження на прик-ладі конкретних регіонів.

Формулювання цілей статті. Дослідження окремих складових елементів соціальної інфраструктури Чернівецької області: освітньонаукового, медичного та спортивно-культурного комплексів, аналіз територіальних відмінностей розвитку соціальної інфраструктури адміністративних одиниць Чернівецької області та динаміка змін показників за останні десятиріччя. Формування комплексу заходів, що покликані покращити стан соціальної інфраструктури регіону.

Виклад основного матеріалу. Забезпечення населення якісною освітою $є$ одним із головних інструментів, що створює можливості для розвитку та реалізації його потенціалу. Освітній комплекс Чернівецької області включає в себе дошкільні навчальні заклади, загальноосвітні навчальні заклади, ВНЗ I-II рівнів акредитації, професійно-технічні навчальні заклади, ВНЗ IIIIV рівнів акредитації. Першою ланкою системи освіти $є$ дошкільне виховання, що представлене дошкільними навчальними закладами належать ясла, ясла-садки, дитячі садки, ясла-садки сімейного, комбінованого, компенсуючого типу (спеціальні та санаторні), навчально-виховні комплекси тощо (Teleshman, 2018b).

Станом на 2019 рік у Чернівецькій області нараховується 372 дошкільних навчальних заклади, 3 яких 97 розташовані у міській та 275 у сільській місцевостях. Незважаючи на загальну тенденцію зростання кількості ДНЗ у області 3 початку століття (для порівняння, у 2000 році кількість таких закладів у регіоні складала 252 одиниці, а у 2010 році - 353), динаміка останніх років $\epsilon$ негативною - кількість ДНЗ у 2019 році на 9 менша, ніж у 2017 році. Зменшення загальної кількості відбувається за рахунок скорочення дошкільних навчальних закладів саме у сільській місцевості, так, наприклад, якщо у міській місцевості станом на 2015 рік було 92 заклади, а у 2019 році цей показник становив 97 закладів, то у сільській місцевості регіону за ідентичний період відбулося

(C) Віктор Телешман 
скорочення на 12 закладів - 3287 у 2015 році, до 275 у 2019 році (рис. 1).

У 2019 році у дошкільних навчальних закладах регіону було 26878 місць та має тенденцію до зростання. Проте, якщо у містах це пояснюється побудовою нових закладів відповідного типу, то у сільській місцевості відбувається за рахунок укрупнення, розширення та покращення умов наявних закладів. Незважаючи на динаміку зростання кількості місць у ДНЗ області, вона не є достатньою, адже кількість дітей у відповідних навчальних установах станом на 2019 рік становила 31196 осіб, тобто на 100 місць припадає 113 дітей, а у міській місцевості досягає 132 осіб на
100 місць. Дошкільними навчальними закладами у регіоні охоплено лише $62 \%$ дітей від загальної кількості дітей відповідного віку (47\% у сільській місцевості, 88\% у міській місцевості). Найвищими показниками охоплення характеризуються міста Новодністровськ та Чернівці - 102\% (враховані діти, що проживають у сільській місцевості та відвідують заклади дошкільної освіти, розташовані у місті Новодністровськ) та $84 \%$ дітей до загальної кількості дітей відповідного віку відповідно. Найнижчі показники характерні для Сторожинецького, Глибоцького та Герцаївського районів (менше $50 \%$ дітей до кількості дітей відповідного віку) (рис. 2).

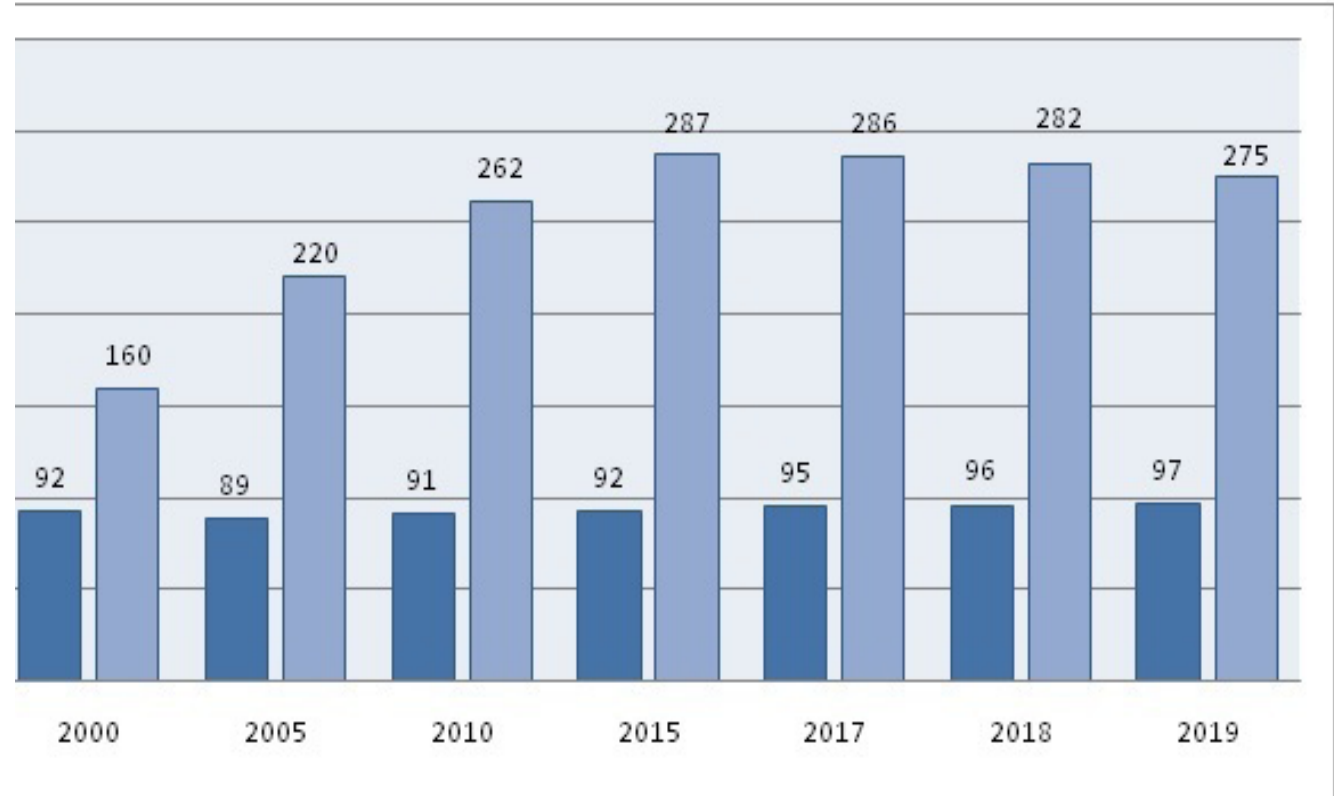

Рис. 1. Кількість закладів дошкільної освіти у Чернівецькій області за типами поселень

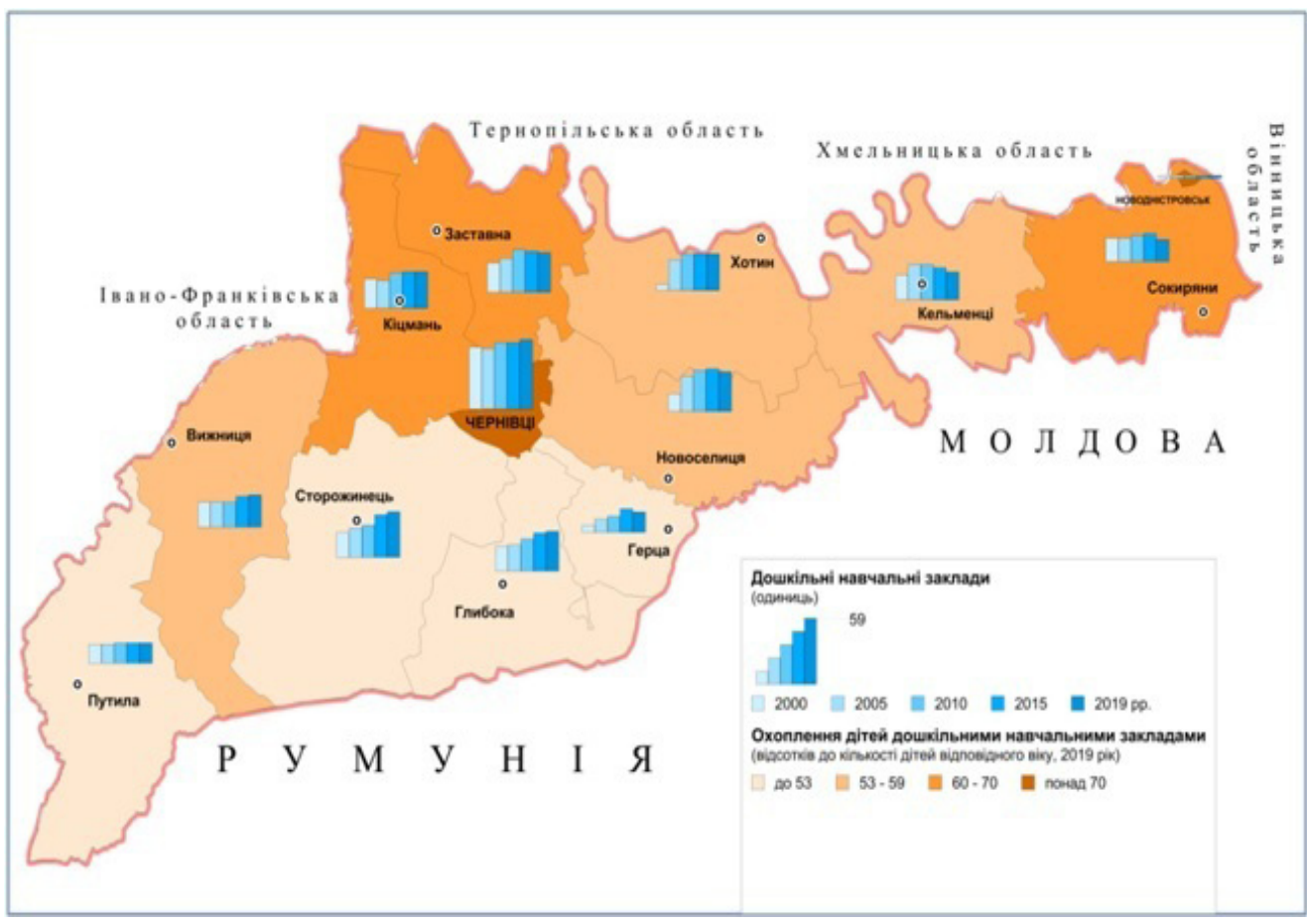

Рис. 2. Розвиток інфраструктури закладів дошкільної освіти Чернівецької області 
Українською мовою виховувалось 90,2\% дітей дошкільних навчальних закладів, що на 1,3\% та 2,4\% менше за відповідні показники у 2010 та 2000 роках. Найнижчі показники україномовного виховання притаманні Герцаївському та Новоселицькому районам, де $85,3 \%$ та $49,9 \%$ дітей відповідно виховувались румунською та молдавською мовами.

Середня освіта у Чернівецькій області забезпечується мережею загальноосвітніх навчальних закладів I, I-II, I-III та II-III ступенів навчання (Teleshman, 2018). Переважна більшість 3Н3 - школи I-III ст. н. $-65,2 \%$, I-II ст. н. - 26,4\%, I ст. н. $6,7 \%$, а частка спеціальних шкіл (шкіл-інтернатів), навчально-реабілітаційних центрів ташкіл соціальної реабілітації - 1,7\% від загальної кількості. Загалом у регіоні спостерігається тенденція скорочення кількості закладів загальної середньої освіти. Так, якщо у 2000 році у області функціонувало 462 3НЗ, то у 2010 році - 447, а у 2019 році лише 403. Найбільша кількість закладів загальної середньої освіти зосереджено у Чернівцях - 59 ЗНЗ, а також у Сторожинецькому та Глибоцькому районах - 46 та 40 навчальних закладів відповідно, найменша ж у місті Новодністровськ - 4 ЗНЗ (рис. 3).

Знижується також і кількість учителів, що забезпечують навчально-виховний процес: якщо у 2015 році їх кількість становила 12,3 тис. осіб, то у 2019 році - 12 тис. осіб, тоді як кількість учнів за ідентичний період зросла 3100 тис. осіб до 105,5 тис. осіб. Середнє навантаження на одного вчителя по області - 8,8 учнів. Найвищим показником характеризуються міста Чернівці та Новодністровськ - 12,0 та 10,6 учнів на одного вчителя відповідно, найнижчим - Путильський та Кельменецький райони $-6,9$ та 6,6 учнів на одного вчителя відповідно.
Денні загальноосвітні навчальні заклади нового типу у регіоні представлені гімназіями, ліцеями та навчально-виховними комплексами. Станом на початок 2016/17 навчального року у Чернівецькій області нараховувалась 21 гімназія (7 у місті Чернівці), що охопила 8,9\% від усіх школярів, 14 ліцеїв (6 у місті Чернівці), які відвідують 5,4\% від усіх школярів та 143 навчально-виховні комплекси де навчаються 20,6\% від усіх школярів (Teleshman, 2018b).

У 2019 році понад 2/3 випускників дев'ятих класів $(67,6 \%)$ перейшли до десятих класів денних закладів середньої освіти, що на 7,7 відсоткових пункти більше, ніж у 2016 році; $0,2 \%$ - до вечірніх (змінних) шкіл; 12,1\% вступили до закладів професійної (професійно-технічної) освіти, а $17,3 \%$ - до закладів вищої освіти, що відповідно на 2,7 та 5,9 відсоткових пункти менше, ніж у 2016 році. Переважна більшість учнів навчається українською мовою і їх часка постійно зростає. Так, якщо у 2000 та 2010 роках питома вага учнів, які навчались українською складала $81,1 \%$ та $83,5 \%$ відповідно, то станом на 2019 рік даний показник становить $86,9 \%$. Другою за поширеністю мовою у закладах загальної середньої освіти є румунська, якою станом на 2019 рік навчається 12,9\% учнів.

За даними Департаменту освіти i науки Чернівецької обласної державної адміністрації станом на 2019 рік у регіоні нараховується 16 закладів професійної (професійно-технічної освіти) у яких на кінець року нараховувалось 5,8 тис. учнів, 3 яких 2,9 тис. учнів випустились протягом року. Більша частина випускників закінчила заклади міста Чернівці - 1,8 тис. осіб, решта - заклади професійної освіти у

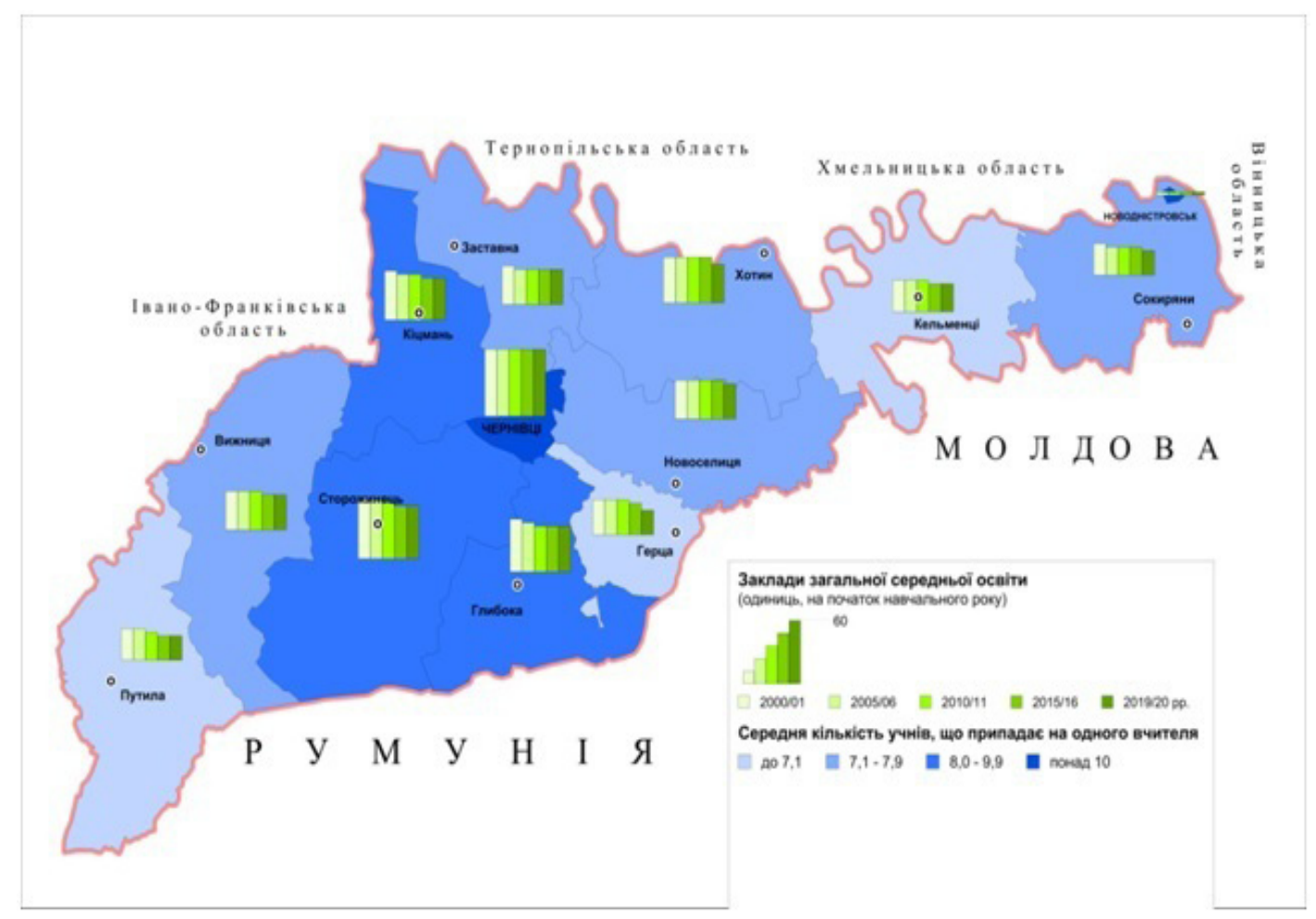

Рис. 3. Розвиток інфраструктури закладів загальної середньої освіти Чернівецької області 
Сокирянському, Кельменецькому, Глибоцькому, Заставнівському та Хотинському районах області. Загалом, розвиток та реформування професійної Чернівецької області відповідає тенденціям загальнодержавного спрямування. Основними стратегічними цілями Стратегії розвитку системи професійної освіти області на період до 2027 року є підвищення ефективності функціонування мережі ЗПО в ринкових умовах та покращення матеріально-технічного стану та доступності ЗПО для вирішення яких сформовано цілу низку операційних цілей та завдань. Так, наприклад, вже у 2021 році було підписано меморандум в межах проєкту «EU4Skills: Модернізація інфраструктури системи професійно-технічної освіти в Україні», завдяки якому три заклади професійно-технічної освіти регіону отримають кошти для модернізації інфраструктури та покращення навчального процесу у них: Чернівецьке вище професійне училищерадіоелектроніки», «Професійно-технічне училище № 8 м. Чернівці», «Вище професійне училище № 24 м. Заставна» (Department...).

Вища освіта Чернівецької області представлена 13 вищими навчальними закладами I-II рівнів акредитації (коледжі технікуми та училища) та 3 вищими навчальними закладами III-IV рівнів акредитації (університети, академії та інститути). Загалом, на початок 2016/17 навчального року у ВН3 різних рівнів акредитації працювало 3039 штатних педагогічних та науково-педагогічних працівників, 3 них 245 докторів та 1323 кандидатів наук, 191 професор та 772 доценти (Teleshman, 2018b).

У вищих навчальних закладах I-II рівнів акредитації станом на 2019 рік навчалося 6,8 тис. студентів, що $\epsilon$ найнижчим показником за останні 20 років. Так, наприклад, на початок 2000/01 навчального року їх кількість у області становила 13,6 тис. осіб, а на початок 2010/11 - 9,0 тис. осіб. Тенденція скорочення кількості студентів спостерігається і у вищих навчальних закладах III-IV рівнів акредитації. У 2019 році кількість їх студентів становила 19,8 тис. осіб, що на 2,5 відсоткових пункти менше ніж у на початок 2015/16 навчального року та на 7,3 відсоткових пункти менше ніж на початок 2010/11 навчального року (рис. 4). Щодо продукування випускників спостерігається зворотна динаміка, якщо у ВНЗ I-II рівнів акредитації кількість випускників за останні 20 років скоротилась майже вдвічі - 3 3,6 тис. осіб у 2001 році до 2,1 тис. осіб у 2020 році, то у закладах вищої освіти III-IV рівнів акредитації, навпаки, зросла майже вдвічі - 3 3,4 тис. осіб у 2001 році до 6,1 тис. осіб у 2020 році.

Станом на 2019 рік у Чернівецькій області функціонує 3 наукові установи та заклади вищої освіти, що мають аспірантуру та в яких отримували відповідний науковий ступінь 244 особи. Також, два ВНЗ регіону мають докторантуру, а кількість докторантів на кінець року складала 10 осіб, що $\epsilon$ одним 3 найнижчих показників за останні 15 років (наприклад, у 2005 та 2015 роках кількість докторантів у наукових установах та закладах вищої освіти Чернівецької області складала 25 та 29 осіб відповідно).

Чернівецька область характеризується високим рівнем наукових кадрів, проте кількість працівників 3 кожним роком зменшується. Так, станом на 2019 рік у виконанні наукових досліджень та розробок було задіяно 609 працівників, що, наприклад, на 200 осіб менше ніж у 2017 році: кількість дослідників та техніків скоротилась на 27,1\% та 46,6\% відповідно, а

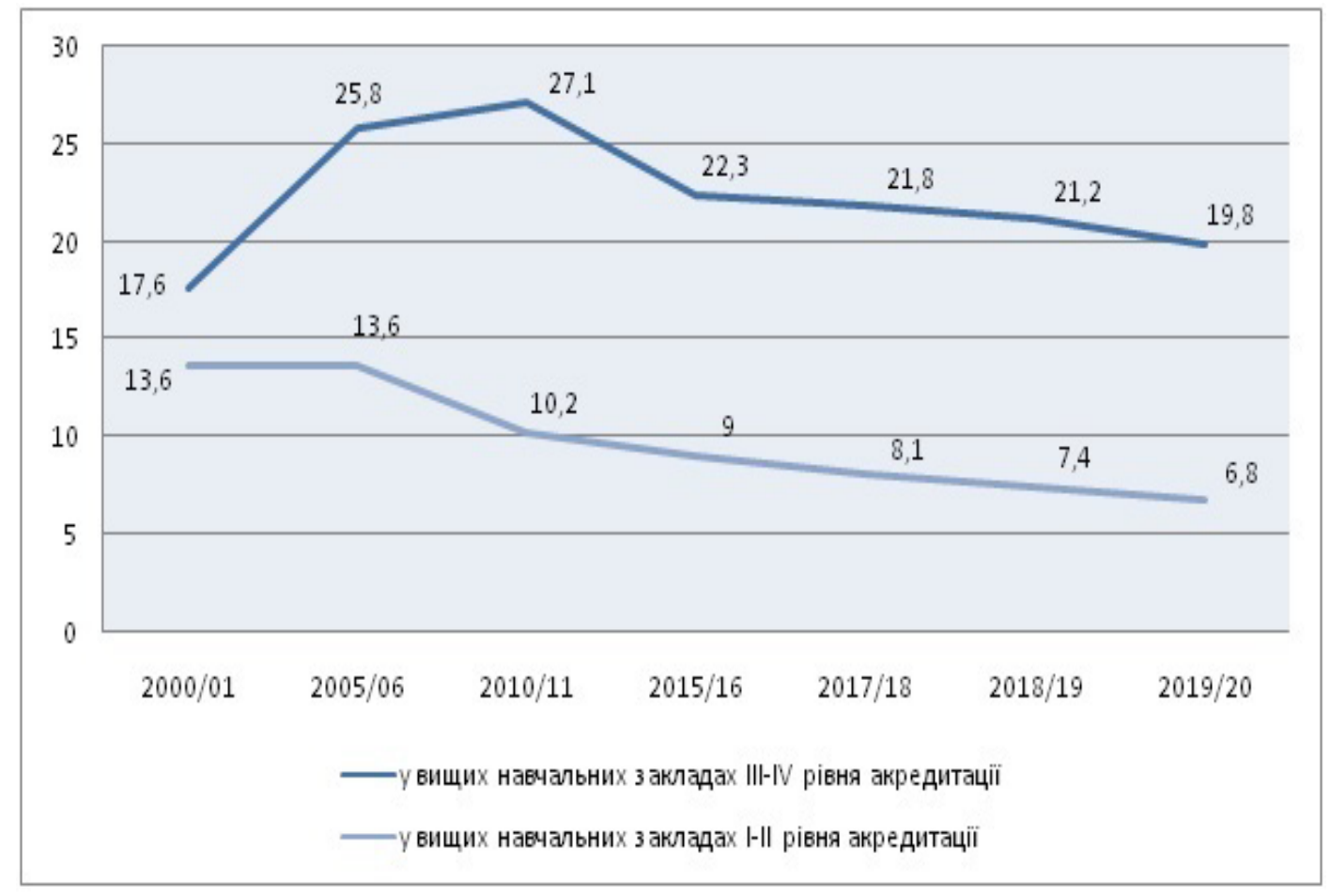

Рис. 4. Розвиток інфраструктури закладів загальної середньої освіти Чернівецької області 
допоміжного персоналу - зросла на 8,4\%. Скорочення кількості виконавців відбувається за рахунок молодших працівників, через що супроводжується зростанням їх середнього віку та збільшенням частки працівників старших вікових груп, якщо у 2017 році частка дослідників віком 60 років і старше становила 20,6\%, то у 2019 році 29,1\%. Окрім цього спостерігається зростання статевих диспропорцій, якщо у 2017 році частка жінок-працівників складала $49,7 \%$ то лише за два роки скоротилась на 2,8 відсоткових пункти і станом на 2019 рік складає 46,9\%. Серед всіх працівників (дослідники, техніки та допоміжний персонал) 84,2\% мають вищу освіту, з яких 33,7\% та 12,2\% мають наукові ступені доктора філософії (кандидата наук) та доктора наук відповідно.

Спостерігається зростання витрат на виконання наукових досліджень та розробок. Так, якщо у 2016 році такі витрати становили 61257,9 тис. грн. 3 яких 71,6\% (43889,8 тис. грн.) пішли на виконання

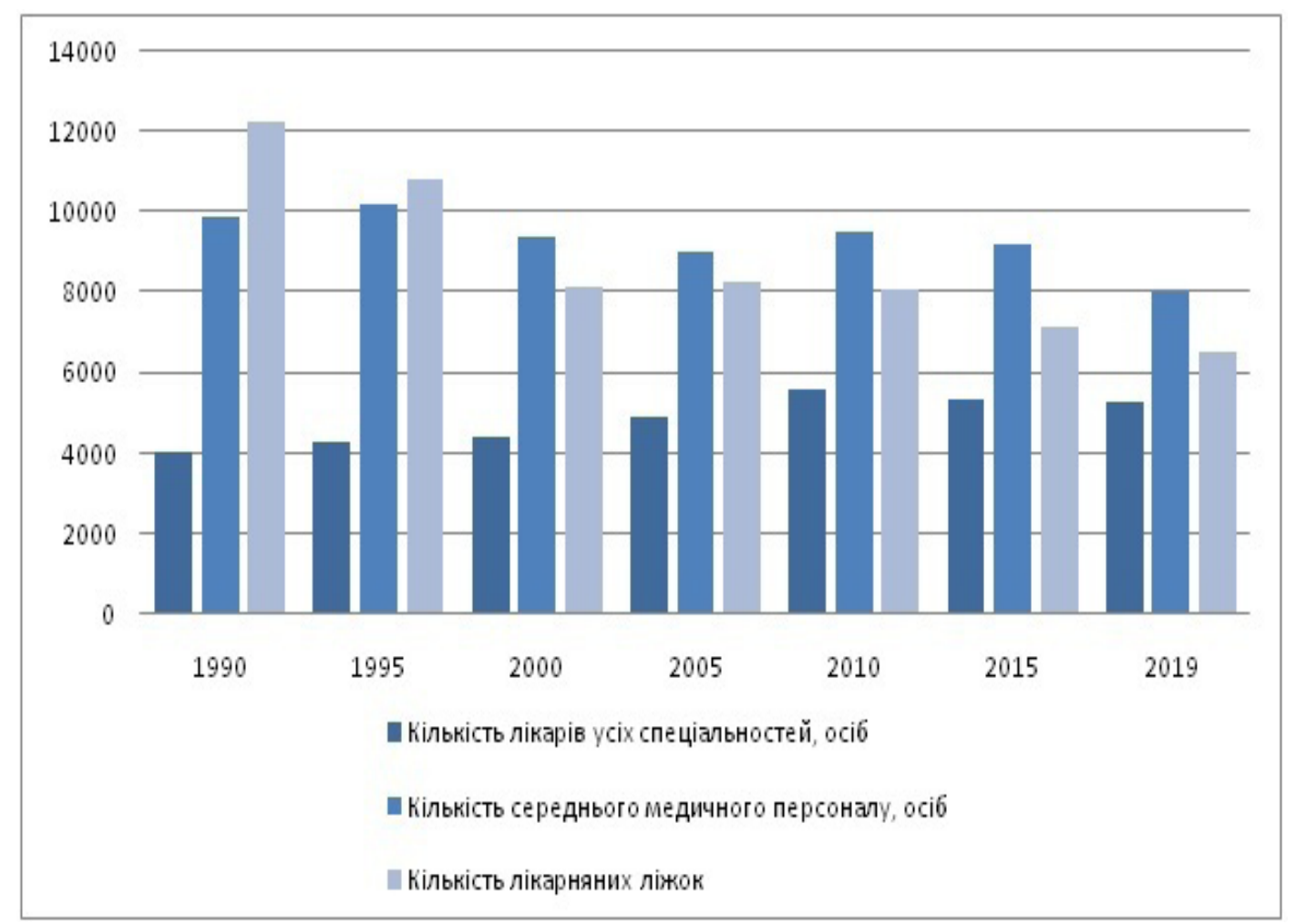

Рис. 5. Мережа та кадри закладів охорони здоров'я

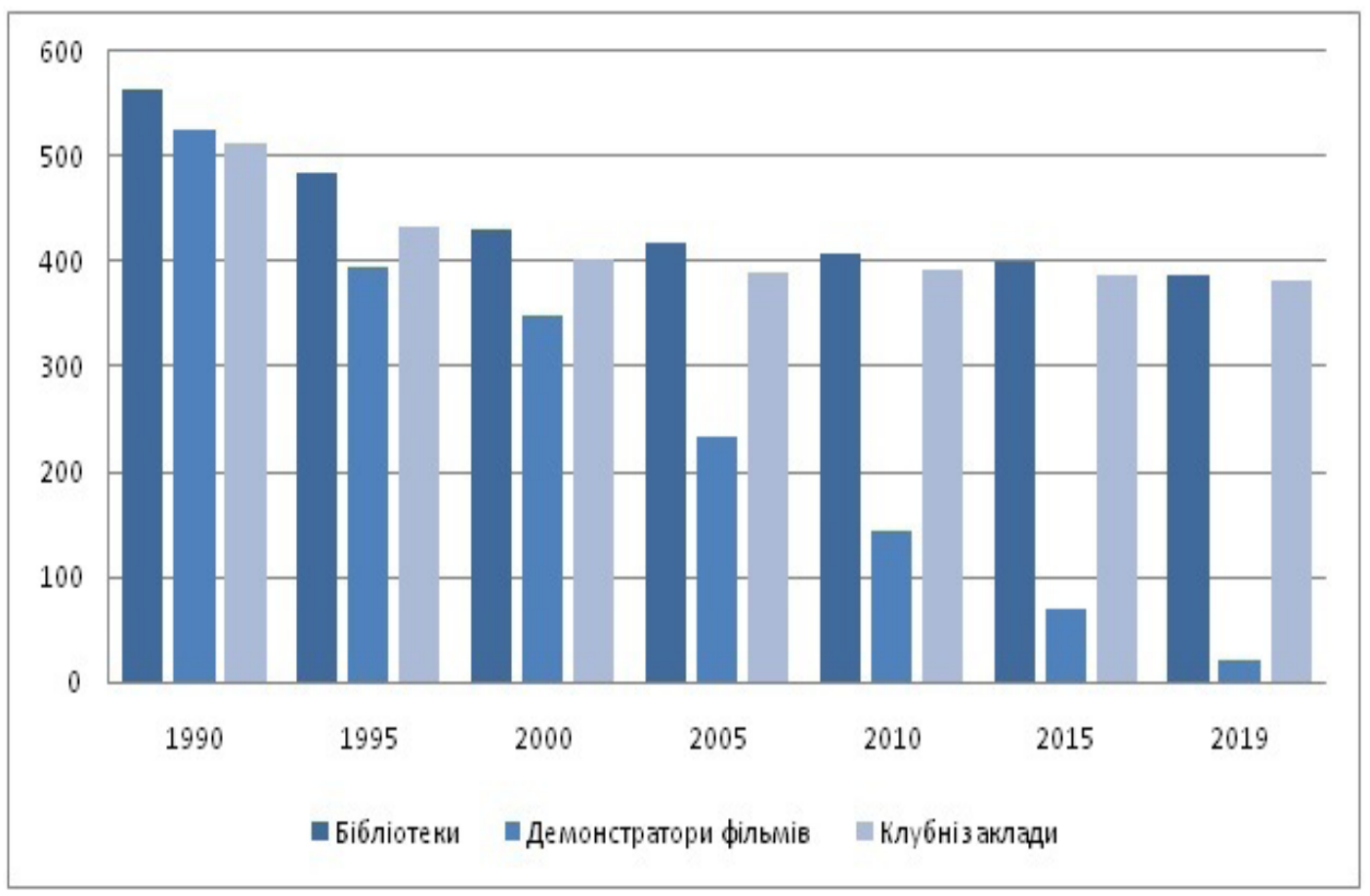

Рис. 6. Основні заклади культури та мистецтва 
прикладних наукових досліджень, а решта - на фундаментальні наукові дослідження та науковотехнічні розробки (43889,8 тис. грн., та 4923 тис. грн. відповідно), то у 2019 році сукупні витрати зросли на 42,1 відсоткових пункти і становили 105729,7 тис. грн., 3 яких майже 2/3 (64,6\% - 68259,2 тис. грн.) надійшло для виконання прикладних наукових досліджень. Проте, якщо у 2016 році iз загальної сукупності коштів понад половину $(52,4 \%)$ надійшли від іноземних джерел, 35,3\% були коштами державного бюджету, а 7,6\% - власними кошти (Teleshman, 2018b), то у 2019 році частка надходжень від іноземних джерел скоротилась на 17,8 відсоткових пункти і становила 34,6\%, що говорить про зниження інвестиційної привабливості.

Розвиток людського потенціалу неможливий без забезпечення населення високим рівнем медичного обслуговування. Елементами компонентної структури медичної сфери РМК Чернівецької області є: лікувально-профілактичні заклади (лікарняні заклади, в тому числі спеціалізовані лікарні; диспансери; амбулаторно-поліклінічні заклади; заклади швидкої i невідкладної допомоги та переливання крові; заклади охорони материнства i дитинства; санаторно-курортні заклади), санітарнопрофілактичні заклади, заклади судово-медичної експертизи, заклади медико-соціального захисту населення, фармацевтичні (аптечні) заклади (Martusenko, 2005).

Станом на 2019 рік у Чернівецькій області функціонує 41 лікарняний заклад 3 сукупною кількістю 6563 лікарняних ліжок та 280 лікарських амбулаторно-поліклінічних закладів. Тенденція скорочення кількості складових мережі та кадрів охорони здоров'я регіону спостерігається ще 3 початку 90-х років минулого століття - кількість лікарняних закладів скоротилась майже вдвічі (на 47,5\%) 31995 року, а лікарняних ліжок у них на 46,4\% в порівнянні з 1990 роком, натомість кількість амбулаторно-поліклінічних закладів у порівнянні з 1995 роком зросла на 93,1\%. Найбільшою кількістю лікарень станом на 2016 рік було забезпечене місто Чернівці (4 міські лікарні), у більшості інших районів області (Гарцаївський, Кельменецький, Путильський, Новоселицький, Сторожинецький, Хотинський) знаходиться лише по 1 центральній районній лікарні, яка обслуговує населення не тільки районного центру, але й прилеглих сіл. У місті Новодністровськ на 10000 населення припадає 84 лікарняні ліжка, що є найвищим показником у досліджуваному регіоні, у обласному центрі ж даний показник найнижчий i становить 14,3 лікарняних ліжка, що пов'язано із значною кількістю населення міста. У районах Чернівецької області показник кількості лікарняних ліжок на 10 тис. осіб варіюється у межах від 56,1 у Сокирянському районі до 38,6 у Глибоцькому районі (Teleshman, 2018a).

За останні десятиріччя також різко зменшилась кількість медичних працівників у регіоні - скорочення кількості середнього медичного персоналу розпочалося ще 3 середини 90-х років минулого століття, і, якщо станом на 1995 рік їх кількість складала 10198 осіб то до 2019 року зменшилась на 21 відсотковий пункт і становила 8056 осіб; кількість лікарів усіх спеціальностей поступово зростала до 2010 року (5588 осіб) проте за останні 10 років скоротилось на 5,1\% до 5301 особи станом на 2019 рік (рис. 5). У місті Чернівці станом на 2016 рік найвищий показник як кількості лікарів на 10 тис. населення i складає (38,3 лікаря на 10 тис. населення) так i кількості середніх медичних працівників на 10 тис. населення $(88,5)$. У Герцаївському та Кельменецькому районах менше 24 лікарів на 10 тис. осіб (20,9 та 22,1 лікарі на 10 тис. населення відповідно), а у Вижницькому районі найменша відносна кількість середніх медичних працівників - 53,3 на 10 тис. населення (Teleshman, 2018a).

Покращення здоров'я та фізичного стану населення - одне із найважливіших завдань медичного комплексу Чернівецької області. Станом на 2019 рік на території регіону діяли 89 закладів оздоровлення та відпочинку, що на 49 одиниць менше, ніж у 2016 році, відповідно, зменшилась і загальна кількість місць у них - 3 2885 до 2349 одиниць (з яких 1915 місць у закладах оздоровлення) у період з 2016 по 2019 рік. Найбільша кількість закладів у 2019 році функціонувала у місті Чернівці (44 одиниці), Новоселицькому та Хотинському районах - по 12 одиниць у кожному, натомість у Кіцманському та Герцаївському районах такі заклади були взагалі відсутні. Місця у закладах оздоровлення та відпочинку області були наявні лише у Сторожинецькому, Заставнівському, Глибоцькому районах та місті Чернівці. Загалом у 2019 році 10690 дітей перебували у закладах регіону, з яких 4344 - у закладах оздоровлення. Загалом питома вага оздоровлених дітей (у загальній кількості дітей віком 7-16 років) в області станом на 2019 рік складала 11\% та варіювалась у межах від 22,8\% та $15,9 \%$ у містах Чернівці та Новодністровськ, до 4\% і менше у Сторожинецькому, Кіцманському, Герцаївському та Вижницькому районах. Для порівняння, усього у 2016 році в регіональних закладах оздоровлення та відпочинку побувало 15717 дітей, а питома вага оздоровлених дітей у Чернівецькій області тоді склала $15,5 \%$ і варіювалась у межах від 2,8\% у місті Новодністровську до 44,4\% у Сокирянському районі.

За останнє десятиріччя у Чернівецькій області зросла кількість спортивних споруд. Так, з'явились нові спортивні майданчики, тенісні корти, футбольні поля, майданчики з тренажерним обладнанням, плавальні басейни, відкрились до того відсутні в області льодові арени, веслувальноспортивна та кінна база, велотрек, стрілецький стенд та стрільбище для стрільби із лука. Проте, скоротилась кількості дитячих спортивних шкіл, у порівнянні з 2015 роком закрилось 3 спортивні заклади і станом на 2019 рік у регіоні функціонує 34 таких школи. Одночасно зменшилась і кількість 
дітей, що займаються в них за ідентичний період на $12 \%$ до 13032 дітей у 2019 році.

Важливою інвестицією в розвиток людського потенціалу населення тієї чи іншої території $\epsilon$ створення та функціонування потужної системи культурно-мистецьких закладів. Об'єкти інфраструктури культури та мистецтва Чернівецької області представлені театрами, музеями, бібліотеками, демонстраторами фільмів та клубними закладами. Починаючи з кінця XX ст. і до нашого часу у Чернівецькій області спостерігається зниження кількості бібліотек, демонстраторів фільмів та клубних закладів та зростання кількості театрів та музеїв.

У регіоні станом на 2019 рік функціонують 387 бібліотек із загальним бібліотечним фондом у 5151 тис. примірників, тоді як у 2000 році розміщувалась 431 бібліотека, а бібліотечний фонд складав 9829 тис. примірників. Найбільша кількість бібліотек у 2019 році функціонувала у Сторожинецькому районі - 41 заклад, Хотинському та Глибоцькому районах - по 37 закладів, найменша - у місті Новодністровськ - 1 заклад. Також, за останні 19 років відбулося скорочення кількості демонстраторів фільмів на 94,3\% 3350 одиниць у 200 році до 20 одиниць у 2019 році (рис. 6). Найбільша кількість демонстраторів фільмів у Вижницькому районі - 7 одиниць, а у Герцаївському, Кіцманському, Новоселицькому, Путильському, Сокирянському, Сторожинецькому, Хотинському районах та місті Новодністровськ їх взагалі немає. Скорочення зазнала і загальна кількість клубних закладів у Чернівецькій області з 403 одиниць у 2000 році до 381 одиниці у 2019 році.

Станом на 2016 рік у Чернівецькій області налічувалось 3 професійних театри (2 музичнодраматичних та 1 ляльковий), які відвідало 72 тис. осіб. Всі театри знаходяться у місті Чернівці. Iз 10 музеїв (6 історичних, 2 комплексні, по 1 мистецькому та художньому) половина знаходиться у місті Чернівці, по 2 музеї у Сокирянському та Глибоцькому районах, та один музей у місті Новодністровськ. Кількість відвідувачів склала 282 тис. осіб.

Висновки. В результаті проведеного дослідження виявлені характерні особливості стану соціальної інфраструктури Чернівецької області. В регіоні простежуються значні диспропорції розвитку освітньо-наукового, медичного, спортивно-оздоровчого та культурного комплексів, та виражається чітка сегментація специфічних проблем, характерних для тих чи інших адміністративно-територіальних одиниць.

Міські поселення, зокрема, Чернівці та Новодністровськ характеризуються, перш за все, недостатнім кількісним розвитком соціальної інфраструктури. Значна частка населення у цих містах формує високий попит та, відповідно, значне навантаження на окремі інфраструктурні елементи: заклади освіти та культури, лікарні, спортивні школи тощо. Проте, у результаті ми бачимо, скоріше, формальну адаптацію соціальної інфраструктури до сучасних викликів, а не її покращення, в тому числі, за рахунок розширення компонентної складової. В свою чергу недостатня кількість інфраструктурних об'єктів у містах, у нашому випадку, призводить до суттєвого дефіциту суб'єктів - фахівців (вчителів, викладачів, лікарів, медичного персоналу), що забезпечують населення освітніми та медичними послугами та $\epsilon$ носіями вмінь i навичок, що безпосередньо впливають на якість та рівень життя населення. Зростання показників кількості учнів чи/та пацієнтів на одного вчителя чи/та лікаря відповідно, є негативною тенденцією, що говорить про невідповідність розвитку освітньо-наукового та медичного комплексів зазначених міст.

Пріоритетним напрямком покращення соціальної інфраструктури міських поселень Чернівецької області $\epsilon$ насамперед швидка та дієва реалізація заходів, направлених на розширення та підвищення якісного рівня інфраструктурної системи міських населених пунктів, зокрема:

$$
\text { розширення мережі позашкільних }
$$

навчальних закладів (насамперед міст Чернівці та Новодністровськ), що вирішить проблему перенавантаження ДНЗ обласного центру та міст регіону загалом;

- збільшення фінансування та покращення матеріально-технічної бази наявних професійнотехнічних навчальних закладів регіону, а також відкриття нових закладів професійної освіти у містах чи містечках (наприклад, у Вижниці, Герці, Кіцмані, Новоселиці, Путилі, Сторожинці тощо);

- підвищення рівня освітнього процесу, впровадження новітніх інформаційних технологій, що дозволить покращити якість надання освітніх послуг у вищих навчальних закладах Чернівецької області та підвищить їх конкурентоспроможність та наукову привабливість для абітурієнтів зокрема 3 інших регіонів України;

розширення мережі лікарняних та амбулаторно-поліклінічних закладів насамперед в місті Чернівці, покращення матеріально-технічної бази медичних закладів міських населених пунктів регіону, покращення рівня надання якісної спеціалізованої медичної допомоги населенню;

- створення культурно-спортивних центрів на рівні міст та містечок регіону; розвиток культурноспортивного кластеру для молоді та професійних спортсменів в Карпатському регіоні області (Вижницький і Путильський райони).

Стан соціальної інфраструктури в районах Чернівецької області має цілу низку проблемних аспектів, що виражаються, насамперед, низькою якістю ¥іi окремих елементів та призводять до скорочення їх кількості передусім у сільській місцевості, а інша частина інфраструктурних об'єктів різного функціонального спрямування $€$ побудованою ще за радянських часів та потребує реконструкції, модернізації, покращення своєї матеріально-технічної бази. Проблема неможливості отримання населенням не просто якісних, a, загалом, послуг, як таких, ставить під сумнів 
виконання будь-яких стратегічних цілей щодо забезпечення соціальних, освітніх, культурних та інших потреб всього суспільства. Відсутність у громад окремих населених пунктів та, навіть, цілих районів Чернівецької області, можливості сходити в кінотеатр чи клубний заклад, отримати базові медичні чи освітні послуги за своїм місцем проживання небезпідставно дозволяє стверджувати про необхідність введення передусім на місцевому рівні комплексних заходів направлених на подолання потужних внутрішньорегіональних та внутрішньорайонних диспропорцій розвитку та доступності об'єктів соціальної інфраструктури, які безпосередньовпливаютьнастворення можливостей для реалізації населення та забезпечують сприятливі умови для розвитку його потенціалу.

Реалізація програми 3 покращення стану соціальної інфраструктури у сільській місцевості Чернівецької області повинна містити низку стратегічних завдань та зважати в тому числі на особливості природних умов території та національний склад населення деяких районів. Головними завданнями вбачаємо:

- оптимізацію та популяризацію дошкільних навчальних закладів, для підвищення показника охоплення дітей відповідного віку зокрема у Сторожинецькому, Глибоцькому та Герцаївському районах (адміністративні одиниці 3 найнижчою часткою охоплення ДНЗ дітей відповідного віку, та, одночасно, найвищою часткою національних меншин - румунів та молдован у національному складі населення);

- забезпечення інклюзивної освіти 3 метою рівних можливостей доступу дітей до якісної освіти та подолання суспільних стереотипів у сільській місцевості;

- розширення мережі лікувально-профілактичних закладів зокрема у важкодоступних сільських населених пунктах гірських районів (Вижниччина та Путильщина);

- створення культурно-просвітницьких публічних просторів завдяки реконструкції сільських закладів культури і мистецтва та їх технічного переоснащення;

- модернізацію та розвиток інфраструктури спорту у сільській місцевості насамперед завдяки забезпеченню та покращенню оснащення на базі закладів середньої освіти.

Повсюдне надання якісних послуг інституціями соціальної інфраструктури для населення, є обов'язком як для органів місцевого самоврядування, так і для держави в цілому. Зважаючи на наявність у Чернівецькій області значних проблем із розвитком комплексу соціальної інфраструктури, доцільним є його розширення та оптимізація, що в свою чергу дозволить підвищити рівень та якість життя населення регіону і забезпечить розвиток його потенціалу.

\section{References:}

Bohun, K. (2013). The role of social infrastructure in the formation of a positive image of the city. Efficient Economy, 3. Access mode: http://www.economy.nayka.com.ua/?op=1\&z=1891 [In Ukrainian]. [Богун К. В. Роль соціальної інфраструктури у формуванні позитивного іміджу міста / Ефективна економіка № 3, 2013]

Department of Education and Science of Chernivtsi Regional State Administration. Access mode: http:// doncv.gov.ua/ [In Ukrainian]. [Департамент освіти і науки Чернівецької обласної державної адміністрації. Режим доступу: http://doncv.gov.ua/]

Gukalova, I. (2009). Quality of Life in Ukraine: Socio-Geographical Conceptualization. Kyiv. [In Ukrainian]. [Гукалова I.В. Якість життя населення України: суспільно-географічна концептуалізація. Київ: ДП «Друкарня МВС України», 2009. 347 с.]

Ivanov, О. (2013). Human potential (formation, development, use). St. Petersburg. [In Russian]. [Иванов О. И. Человеческий потенциал (формирование, развитие, использование) монография. Санкт-Петербург]

Kinash, I. (2012). Composition and structure of social infrastructure. Visnyk sotsialno-ekonomichnykh doslidzhen - Socio-Economic Research Bulletin, 3(46), 2, 171-176 [in Ukrainian]. [Кінаш І. П. Склад і структура соціальної інфраструктури / Вісник соціально-економічних досліджень. 2012. Вип. 3(2). С. 171-176]

Martusenko, I. (2005). Territorial Organization of the Medical Complex of Vinnytsia Region. PhD thesis. [In Ukrainian]. [Мартусенко I. В. Територіальна організація медичного комплексу Вінницької області. : Дис. канд. наук: 10.01.02. 2005.]

Pihul, N. (2013). The essence and importance of social infrastructure. Scientific Bulletin of Poltava University of Economics and Trade. Series "Economic Sciences", 2, 37-41. Access mode: http://journal.puet.edu.ua/index.php/ nven/article/viewFile/678/749 [In Ukrainian]. [Пігуль Н. Г. Сутність і значення соціальної інфраструктури // Науковий вісник Полтавського університету економіки і торгівлі. Сер. : Економічні науки. 2013. № 2. C. 37-41. Режим доступу: http://journal.puet.edu.ua/index.php/nven/article/viewFile/678/749]

Pihul, N. (2014). Social infrastructure: functionality and features of development. Economic Analysis, 1, $171-176$. Access mode: https://essuir.sumdu.edu.ua/bitstream-download/123456789/53037/7/Pihul Sotsialna infrastruktura. pdf [In Ukrainian]. [Пігуль Н. Г. Соціальна інфраструктура: функціональне призначення та особливості розвитку. Економічний аналіз. 2014. Т. 16, № 1. С. 117-122. Режим доступу: https:/essuir.sumdu.edu.ua/bitstre amdownload/123456789/53037/7/Pihul_Sotsialna_infrastruktura.pdf]

Saliy, A. (2012). Functional purpose and main tasks of social infrastructure of Ukraine. Science and Economics, 18(2), 215-218. [In Ukrainian]. [Салій О. М. Функціональне призначення та основні завдання соціальної 
інфраструктури України // Наука і економіка. 2012. № 2 (18). С. 215-218]

Novikov, V., Deeva, N., Gvelesiani, A., et al. (2018). Social Infrastructure on the Way to Reforming Local Self-Government. Kyiv-Warsaw, 2018. [In Ukrainian]. [Соціальна інфраструктура на шляхах реформування місцевого самоврядування: кол. моногр. / В. М. Новіков, Н. М. Дєєва, А. Г. Гвелесіані [та ін.]; за наук. ред. д.е.н., проф. В. М. Новікова; д.е.н. ( хабілітованого), проф. Здіслава Сіройча. Київ-Варшава, 2018. 431 с.]

Teleshman, V. (2018a). Medical-Geographical Complex of Chernivtsi Region: Formation and problems of development. In Shevchenkivska Vesna - 2018. Geography: Collection of Scientific Works of the XVI International Scientific Interdisciplinary Conference of Students, Postgraduates and Young Scientists. Kyiv: Print Service. [In Ukrainian]. [Телешман В. I. Медико-географічний комплекс Чернівецької області: формування та проблеми розвитку / Шевченківська весна - 2018. Географія: Збірник наукових праць XVI міжнародної наукової міждисциплінарної конференції студентів, аспірантів та молодих вчених. Київ: ПрінтСервіс, 2018]

Teleshman, V. (2018b). The educational complex of Chernivtsi region and perspectives of its development. Geography and Tourism, 40, 156-162 [In Ukrainian]. [Телешман В. І. Освітній комплекс Чернівецької області та перспективи його розвитку. Географія та туризм. Вип. 40. С. 156-162.]

Yagodka, A. (2000). Social Infrastructure and Policy. K.yiv: KNEU. [In Ukrainian]. [Ягодка А. Г. Соціальна інфраструктура і політика. Київ: КНЕУ, 2000. 212 c] 